Article

\title{
Identification and Analysis of Agricultural Externalities (A Valuation Methodology on Examples)
}

\author{
Rafał BAUM"1, Magdalena KOZERA-KOWALSKA ${ }^{2 *}$ \\ ${ }^{1}$ Poznan University of Life Sciences, Poznan, Poland; email: rafal.baum@up.poznan.pl \\ 2 Poznan University of Life Sciences, Poznan, Poland; email: mkozera@up.poznan.pl \\ *Correspondence: mkozera@up.poznan.pl;
}

\begin{abstract}
The agriculture and rural areas perform a new function which requires the delivery of public goods to the society. In turn, a comprehensive identification and analysis of agricultural externalities (external economies) involves a need for developing a dedicated valuation methodology. This paper presents the assumptions of the public goods theory and puts them in the context of agriculture. The study focuses on analyzing the valuation methods for external economies, and proposes a methodology for the valuation of some illustrative positive externalities of agricultural production and of natural environment resources regarded as public goods (the agritourist value of a farm and the value of a natural waterhole).
\end{abstract}

Keywords: Agricultural Externalities, Public Goods, Sustainable Agricultural Development, Multifunctional Agriculture.

JEL Classification: D62, H41, Q01, Q51, C20

\section{Introduction}

The agriculture and rural areas are an open system composed of three interdependent and intertwined subsystems: the social, economic and environmental subsystem. So far, their development has been based on models focusing on the economic function (making microeconomic decisions so as to maximize economic benefits). However, that approach became widely criticized because neither the environmental balance nor the social balance are addressed if the economic balance is attained at the maximum profit level. Moreover, the agricultural economists argue thatin addition to positive production and economic effects-the intensification of agricultural production results in a series of adverse environmental impacts. Over the years, the preponderance of private economic rationality over general social rationality in farming has resulted in agricultural development to the detriment of the natural environment and its non-renewable resources (Baum 2007), (Baum 2011), (Piontek 2002), (Runowski 2005), (Woś 2002).

The problems described above forced a series of amendments to the European Union's Common Agricultural Policy (CAP). Meanwhile, a shift in approach to agricultural and rural functions resulted in establishing new development models for them. Sustainable agriculture and multifunctional agriculture are the most widely discussed and most promoted models.

Underpinned by environmental aspects, the first one focuses on an economically viable, socially responsible and environmentally-friendly agricultural sector. The second one primarily addresses the socio-economic issues and assumes that agriculture, in addition to food, should also deliver other goods while preserving the culture and landscape of rural areas. When analyzing the above models in the context of theoretical assumptions of new institutional economics, it can be noted that a major role is played by state institutions which somehow take over the prerogatives of free market mechanisms. Also, they act in line with social responsibility principles, protect the natural environment, implement the non-food production paradigm and preserve the landscape and culture, 
which makes their operations consistent with the concept of the public goods theory. Thus, the agriculture has now a new function which will require the delivery of benefits to the whole society in return for payment by the government (Adamowicz 2005), (Baum 2009), (Maciejczak 2009), (Majewski 2008), (Sadowski 2009), (Wilkin 2009), (Zegar 2012).

A characteristic feature of agriculture is the presence of multiple side effects of farming which may be either positive or negative externalities. The first ones (benefits) are related to a multifunctional and sustainable development of agriculture (in addition to foodstuffs, the agriculture delivers other "products" referred to above: non-tradable goods and services with a positive impact on natural environment). The second ones, external costs, may result in the degradation of natural resources (landscape, biodiversity or soil fertility) if improper agricultural practices are used, for instance.

If external costs and benefits are to be covered by production function models, a problem emerges which is how to appraise the externalities. The economists say openly: "it is difficult, if not impossible, to measure the externalities; a Chicago economist is one who is only about to discover them" (Landreth 1998).

Therefore, there is increased demand for an appraisal of agricultural and rural externalities which involves the following prerequisites: a complete analysis of economic viability of agricultural production; construction of financial support instruments for the farmers to compensate them for the delivery of environmental services; analysis of social costs and benefits of municipal investments; estimation of environmental penalties and duties etc.

The purpose of this paper is to present the assumptions of the public goods theory and to put them in the context of agriculture and rural areas regarded as providers of positive externalities. Another objective is to analyze the valuation methods for externalities and to propose a methodology for the valuation of illustrative cases of positive externalities of agricultural production and of natural environment resources considered to be public goods. The considerations are based on a scientific literature study and on own research.

\section{Definition of external economies}

External economies (externalities) is a term first used by Alfred Marshall (Marshall [1890] 2018), a Briton and one of the founders of neoclassical economics. The research on external economies was developed and incorporated into economic sciences by Arthur Pigou (1887-1959), co-author of welfare economics. In welfare economics, Pigou distinguished between private and social benefits and between private and social costs. He referred to the divergence between private and social benefits or costs as "external economies," which is consistent with today's definition of the term (Pigou [1932] 2018). The Dictionary of Economics defines external economies as a benefit or cost which results from an activity but is not assigned to a person or organization who performs it (Black 2009). To put it in yet other terms, the result of external economies of market goods is that specific goods and services are used not only by those who purchased them but also by other consumers for whom they represent a benefit or a disadvantage. Therefore, external economies may be both positive or negative, depending on the circumstances (Samuelson 1995), (Samuelson 1996), (Stiglitz 2004). This is perfectly illustrated by positive effects of preventive vaccination and negative consequences of environmental degradation. Sometimes, external economies are mistakenly assimilated to side effects, i.e. epiphenomena of certain events or areas of human activity (for instance, occupational diseases and accidents at work are a negative side effect of production activities) (Wesołowska [2004] 2018)

\section{Public goods theory}

The theory of public goods is a part of a broader theory of public choice (also referred to as the economic theory of politics) which includes the economic theory of democracy, the interest group theory, the common goods theory and the analysis of rent-seeking mechanisms. All of the above theories exist within the framework of new institutional economics (Wilkin 2005). 
The economic theory mostly analyzes private goods which may be distributed, sold at a specific price, and purchased in quantities depending on the buyers' preferences and financial resources. Also, there are common goods defined as public goods. Their characteristic feature is that no one can be excluded from consuming or benefiting from a specific quantity of a good, once delivered to the market (whether the buyer/user paid for it or not). Another feature of public goods is the noncompetitiveness of consumption which means a certain quantity of a public good may be used to the same extent by all users. In other words, an individual consumption of a public good by one person does not restrict in any way the individual consumption thereof by another person (Holcombe 1997) (Maciejczak 2010) (Samuelson 1954).

The classification presented above may be supplemented with club goods which can be excluded from consumption and are not consumed on a non-competitive basis, and with common goods which cannot be excluded from consumption but are consumed on a competitive basis (Figure 1).

If the ability to generate positive or negative side effects is used as a criterion, the classification of goods, as shown in the figure, should be supplemented with merit goods and demerit goods (Rogall 2009) (Wesołowska [2004] 2018).

Merit goods (which some believe to be identical to common goods) are desired by the society and are produced in the mutual interest of society members. The importance and value of these goods is reflected even by their etymology. The characteristic feature of merit goods is that they provide benefits accessed on a competitive but rarely exclusive basis; they do not only provide benefits to the buyer but also bring positive externalities to the society; and that for various reasons (e.g. ignorance of their importance) the consumers do not spend enough money on them to ensure an optimum delivery thereof to the society. This confirms that merit goods are affected by market failure, and therefore the state (politics) must ensure the delivery or co-financing of such goods with political and legal instruments. Merit goods include taking care of the elderly, healthcare, education or protection of natural resources.

\begin{tabular}{|l|c|c|c|}
\cline { 3 - 4 } \multicolumn{2}{c|}{} & \multicolumn{2}{c|}{ The possibility of exclusion from consumption } \\
\cline { 3 - 4 } \multicolumn{2}{c|}{} & YES & NO \\
\hline \multirow{2}{*}{$\begin{array}{c}\text { Competitiveness of } \\
\text { consumption }\end{array}$} & YES & Private goods & Common goods \\
\cline { 2 - 4 } & NO & Club goods & Public goods \\
\hline
\end{tabular}

Figure 1. Classification of goods according to economic theory.

Demerit goods are goods whose consumption contributes to negative externalities. Therefore, state intervention (bans, information campaigns, taxes) should restrain or reduce the related demand. The most common examples include legal and illegal drugs: alcohol, tobacco or narcotics. However, in the real world, goods whose consumption generates social costs (e.g. health and environmental burden) are much more numerous.

According to the assumptions of new institutional economics, the delivery of public goods is a problem which cannot be solved based exclusively on market mechanisms. In the context of public goods, all of their benefits are external, i.e. the goods are used by all consumers rather than only by buyers. External economies may be removed or strengthened by implementing proper taxes and subsidies. This can be done based on the Coase theorem (positive external economies) or with the Pigou tax (negative external economies). Whether positive or negative, external economies result in a Pareto inefficient allocation of resources and, as the reason behind the failure of market mechanisms, are used as an argument for state intervention (Coase 1960) (Fiedor 2002) (Maciejczak 2009) (Pigou [1932] 2018).

Therefore, new institutional economics call the state institutions to intervene and exert an impact on the production of public goods by stimulating actions to achieve positive external economies. This 
is related to the fact that positive external economies lead to social benefits. In a classical approach, public goods are characterized by two essential features: no one can be excluded from the consumption of such goods (non-exclusivity) and are consumed on a non-competitive basis (noncompetitiveness). The first condition means the supplier is unable to legally prevent other people from using the good. The second means that if the good is consumed by someone, other people may still consume the same good (the good may be consumed by many persons concurrently with no consequences).

\section{Delivery of public goods as a new function of agriculture}

The CAP evolves towards increasing the scope and level of support for rural areas. Gradually, the agricultural policy transforms into a comprehensive state policy for rural areas which considers agricultural production to be one of the many aspects of rural development. This means a shift from a sectoral approach towards a territorial approach. An important part of CAP is the linkage of payments to the obligation to meet specific quality standards by the farms, e.g. cross-compliance or "greening".

Each member country shall adopt and use appropriate instruments adjusted to diverse natural, economic and organizational conditions of local agriculture. A long-term development of rural areas as a whole (and as a component of sustainable national development) is planned. While addressing the quality of life of the entire society and efficiently managing natural resources (by using renewable and non-renewable energies), it will preserve the beauty of a varied landscape and nature. According to that new vision, the farmers, as suppliers of public goods (such as pure soil and water, rural biodiversity, traditional rural landscape) to the entire society, should be remunerated for doing so (FAPA/SAEPR 2006), (Łuczka-Bakuła 2006).

The adoption of that concept also results from the modification of the term "public goods" itself. The definitions of public goods used today by the economists are not totally consistent with the everyday meaning of that term which is considered to be a good available to (and intended for) everyone, related to an office or a non-private institution (a similar definition was used in the economics in first half of the twentieth century and continues to be often used in political discourse). Defined as such, public goods are usually referred to by the economists as social goods. These are goods that could be private goods but for various reasons (generally due to the social policy in place) are available to every citizen and are financed with public funds (e.g. education, healthcare).

If the government is willing to pay the farmers for the production of public goods, this is not only because the public good cannot be commercialized (no one will undertake to produce and sell the good because no one would want to buy it since everyone may consume it for free). Instead, the main reason is that the state is unable to produce such goods by itself. At the same time, state intervention in the form of subsidies is a specific way to safeguard the interests of the citizens against increased competition in the consumption of goods manufactured by the farmers or against any limitations in accessing the goods (against a total or partial exclusion from consumption).

In summary, on a European-wide basis, agricultural support tends to rely on intermediate measures which means support for rural areas. A network of instruments for the protection of the natural and cultural environment is being developed to improve the viability of rural areas. Because the prices will be increasingly strongly determined by the global market, direct support instruments (especially price support instruments) for the farmers will become less and less important in the future. This explains the major and growing role of non-market functions of the agricultural sector in its further development. And therefore, the analysis of economic viability must go beyond direct microeconomic benefits determined by the market. It is in the public (macroeconomic) interest to protect the "silent" market players (future generations, social values, environment) while also eliminating external costs and stimulating the delivery of public goods (external benefits); this should be the target of the policy under which the abovementioned reorientation already takes place (Zegar 2007). 


\section{Methods for the valuation of external economies}

The relevant literature identifies multiple methods for the valuation of external economies (Graczyk 2010), (Grzelak 2013), (Maciejczak 2009), including: travel cost, hedonic pricing, contingent valuation (WTP and WTA), production effects, human capital (illness cost method, health production function), cost minimization, declared preferences, action-reaction, costs of lost benefits (opportunity), replacement (reinstatement costs) method, preventive method. Based on the procedure for the valuation of non-market goods, the methods listed above may be classified into two groups (direct and indirect methods). In the first group, economic values are determined by assessing the substitute markets where people sell and buy goods that are complementary to the one in question. The second approach addresses a hypothetical market where the good could be bought and sold; people are asked directly about their Willingness To Pay (WTP) for what they do not own or about their Willingness To Accept (WTA) a compensation for abandoning something they have (Żylicz [2013] 2018).

Each method has its own limitations and is mainly based on artificial structures and intermediate estimations which, in turn, require many assumptions and an extended mathematical approach. As a consequence, different methods often provide different results. It is very difficult to estimate human impact on the growing environmental threats (whether today or in the future).

If the economic models fail to include the negative and positive human impacts, some forms of activity may be overestimated or underestimated (as regards agriculture, this could be the case for industrial fattening or extensive grazing, for instance). Such errors will blur the image and distort the valuation in a general social perspective. Therefore, it seems imperative to identify the non-market functions of agriculture (in addition to identifying its market functions). This is a multidimensional problem because of the complexity of interactions between agriculture and its environment (Wilkin 2009).

According to Grzelak (Grzelak 2010), even though multifunctional agriculture is relatively inefficient from the microeconomic perspective (the output/input ratio), it adds more value to the socio-economic system if such external economies are taken into account. Finding the optimum between the maximization of microeconomic outputs (at farm level) and the reduction of negative external economies (while promoting positive externalities) requires taking institutional measures to internalize these effects. The measures include: disincentives in the form of fees (e.g. environmental fees), and penalties or taxes (Pigou tax) imposed upon exceeding certain norms; incentives which mean promoting specific environmentally-friendly behaviors, implementing the Code of Good Agricultural Practice, establishing and refining property rights (the Coase theorem); and actions taken to include the above elements in the cost-benefit analysis.

\section{Valuation of selected external economies of agriculture}

Below you may find two examples of a methodology for estimating the value of agricultural externalities. Positive effects (benefits) subject to valuation are related to a multifunctional, sustainable development of farms and mean preserving the rural landscape and biodiversity. In the first case, the agri-tourist value of a farm (defined as the value of a specific location brought by the natural beauty of the landscape and leisure services produced by environmental assets) was analyzed. An assumption was made that such activities as strolling, nature spotting, camping, barbecuing etc. would be impossible without the territory where they take place (leisure services are enabled by the use of natural resources which are available within the farm and are taken care of and preserved by the farmer). In the second case, the value of a natural waterhole was assessed as an element that enhances the biodiversity of agricultural ecosystems. Found in a quite large number of circumstances, a waterhole is an important component of biodiversity (for instance ponds, waterholes, natural water bodies and streams are found in $20 \%$ of farms in the Wielkopolska region in Poland).

The Travel Cost Method (TCM) may be expected to be one of the most suitable methods for the valuation of leisure and tourism functions of farms. As a main advantage, it is based on observable human behavior which makes it a reliable approach. TCM is the oldest method for the valuation of 
environmental resources. It was first proposed by Harold Hotelling (1949), an American economist, and was broadly used in the US to determine the value of recreational venues, such as parks and areas of high landscape values. The method is essentially based on the assumption that the value of the area under consideration is reflected in travel costs incurred by consumers: the more they value the destination, the more they are willing to pay for traveling there (their interest is driven by specific real services provided by the environment: trekking, swimming, fishing etc.). Therefore, the costs incurred may be considered as the value of the area or the probable price the public is willing to pay to preserve its usability (Panasiuk 2001), (Shechter 1996).

Two versions of the Travel Cost Method exist: costs of traveling from given zone and individual travel costs. This paper proposes the use of the second approach which is based on a survey asking the respondents (people who traveled to and stayed in an agri-tourism farm) about the number of visits per year and the travel costs: transport costs, the value of time spent on leisure activities, accommodation costs and other local expenses.

The detailed questions included in the survey should address the following: the number, age, gender and degree of relatedness of people traveling as a single group; number of visits to the farm within a year (and the total number of visits); place of residence of the tourists; distance traveled $(\mathrm{km})$; route traveled (direct or indirect); means of transport (e.g. vehicle type and engine capacity [cm3]); estimated cost of traveling (including fuel, automotive fluids, tickets etc.); time and estimated cost of traveling; duration of stay (number of overnights); accommodation and catering expenses (an increase in eating-out expenses); and the loss of remuneration, if any, related to the holiday trip (obviously, the best option would be to survey all visitors to an agri-tourism farm within a year).

Travel costs $[\mathrm{C}]$ are calculated as:

$$
C=(K p+K c+z \cdot K n+K w+K z)
$$

with:

$K p$ : transport costs,

Kc: costs of time lost (when traveling),

$z$ : number of overnights,

$K n$ : daily accommodation costs,

$K w$ : catering costs incurred during the stay (the excess over catering costs incurred at home),

$K z$ : costs of lost remuneration.

The value calculated above may be regarded as the agri-tourism (service) value of the farm. If the farm (especially the building with guestrooms and related facilities) is considered to be an object with a limited lifetime, the present value of the annual flows of agri-tourism service values may be calculated for the expected further lifetime (the year of construction needs to be determined, and the remaining lifetime has to be estimated based on the expected operational life). Next, under the assumption that the interest in spending holidays at the farm will remain at the base year level, the Net Present Value (NPV) may be calculated for that period. Because it is still difficult to reliably assess the inflation rate in subsequent years, the best option is to adopt a simplified approach with constant prices and a discount rate which does not include inflation. In this case, the real interest rate on secure assets (e.g. 10-year bonds) may be used as the discount rate. For example if the annual interest rate on these assets was e.g. $3 \%$ and the inflation rate was $0.5 \%$, the real interest rate would be $2.5 \%$. Once the discount rate is set, the agri-tourism value of the farm may be easily calculated.

The calculations do not require any tourists to be excluded, unlike the valuation of landscape parks or natural reserves (e.g. school children on field trips who do not make their own decision to visit a specific destination) where traveling costs should not be calculated. Combined trips are a methodological difficulty in the TCM because the location considered is only one part of the journey. One way to solve it is to specify the percentage share of the farm in total trip costs which, however, may be difficult for the interviewees. Another problem emerges if the tourist trip involves visiting other destinations located nearby (which happens quite often). It also remains debatable whether accommodation costs should include fees related e.g. to entrance tickets for national parks and museums, beach parking costs etc. (it seems this should not be the case because these expenses do not add to the tourist value of the farm under consideration). 
Another example of a methodology for the valuation of agricultural ecosystem resources as public goods consists in appraising a waterhole at replacement cost. This allows to determine the value of an environmental resource or asset based on the amount of physical and financial inputs which are necessary to rebuild it. The essential information may be obtained based on observations or expert opinions. If input data is properly defined, reinstatement costs may be determined with considerable confidence. The method is reliable and transparent.

A "waterhole" is defined neither in technical literature nor in technical and construction regulations for hydraulic engineering or land improvement. In plain language, a waterhole is a small lagoon, reservoir or body of water. According to the Water Law, a waterhole is classified as standing water, i.e. smaller bodies of water which are not connected to flowing water (usually, these are discharge lakes, ponds, clay pit ponds, flooded mine subsidence holes, flooded peat pits, field ponds or meadow ponds).

To properly value an asset, it is imperative to draw up a detailed list of expenses, which is possible only upon a prior comprehensive analysis of the body of water concerned. The reliability of calculations depends on multiple conditions; the initial assumption should address the characteristics of the waterhole, such as: shape, water surface, location, depth, shape (inclination) of slopes, species and quantities of aquatic plants in different zones of the body of water (marsh plants, shallow water plants and deep water plants), quantity of excavated materials, sealing agent (clay, nonwoven fabric), material used to line the body of water (sand, gravel, peat), water source etc.

The analysis allows to identify the following physical and financial inputs:

- soil excavation and disposal;

- production and delivery of clay blocks;

- sand and gravel, including transport;

- polyethylene film and nonwoven fabric, e.g. hydrotex;

- water plants and plant containers;

- peat insert for waterholes;

- other material costs (perforated tubes, geotextiles, grass seeds etc.), costs of services (clay compaction);

- labor costs: ground works, planting etc.;

- documentation costs and administrative fees.

The value calculated as the total of physical and financial inputs necessary to rebuild the asset may be considered to be the value of the waterhole as an environmental (agricultural ecosystem) asset.

The reinstatement cost method underestimates the environmental assets for many reasons, including the fact that some environmental components cannot be reinstated or that it takes a long time to reinstate them (e.g. natural restocking of fish, colonization by amphibians, insects, birds etc.). However, this method seems to be useful especially in cases of environmental pollution or degradation. This is because the persons held responsible for the pollution (or forced to live in a degraded environment) can see the amount of losses and therefore take preventive measures or restore the status quo ante.

\section{Initial research results}

In a selected farm, located in a small village by the Baltic Sea (on the outskirts of the National Park), preliminary surveys were carried out from June to September. The survey was completed by 38 people. This number corresponded to the number of groups of tourists (the size of individual groups ranged from 1 to 5 people), while in general, 105 people traveled in all groups. According to the information obtained from the owner of the agritourism farm on the use of rooms and camping throughout the year, the total number of groups (and tourists) of visitors and vacationers on the farm was established. Next, the annual travel costs [C] of all tourists were determined. They amount to PLN 218,700 (150 groups of tourists - a total of 442 people). The above value can be considered as the agritourism value (services) of the farm. If we treat the farm (especially a building with rooms for letniks with infrastructure) as an object of limited durability, we can calculate the current value of the 
stream of annual values of agrotourism services in the anticipated, further period of operation. Estimated - by the expert method - the further life of the building for vacationers is 19 years. Assuming that in the following years the interest in leisure on the farm will be maintained at the current level, NPV was calculated for this period (assuming the above assumptions regarding the discount rate). The farm's agritourist value amounted to over PLN 2,500,000.

In the second case, the value of the pond as a value of the natural environment (agricultural ecosystem) was calculated according to the methodology proposed earlier. On the basis of estimated amounts of material and financial inputs necessary for the reconstruction of the water reservoir, the value of the water pond was established for ca. 28,000 PLN.

\section{Final considerations}

Today, highly developed countries pay less and less attention to the need for food securitywhile increasingly focusing on the protection of agri-ecosystems. The growing environmental awareness of the population also plays an important role (the following issues are concerned: low quality of industrially produced food; food waste; maintaining the rural landscape; the declining biodiversity etc.). This is particularly important for the agriculture which generates considerable externalities , both positive and negative (the externalities depend on the agriculture model underpinning the production of agricultural commodity). The market mechanism automatically triggers an excessive production of negative externalities and an insufficient production of positive externalities to address social needs. Therefore, it is imperative to implement political measures to narrow the gap between economic competitiveness and social competitiveness which result in attaining the economic optimum and the social optimum, respectively.

Some attempts to regulate the externalities of economic activity can be seen in the EU policy and in intentional measures taken by particular countries to reduce or internalize external costs and to support public goods. The CAP reforms, including the introduction of instruments for the restoration, preservation and enhancement of ecosystems dependant on agriculture, have a potential impact on the occurrence of external economies (reduction of external costs) and on the support for (creation of) public goods, especially as regards soil protection, agricultural biodiversity and health quality of food.

Changes caused by a shift in perception of agricultural functions have led to the establishment of new agricultural development models. The agriculture and rural areas have now a new function which requires the delivery of benefits (public goods) to the whole society in return for payment by the government, i.e. by the society.

Both the theoretical and empirical aspects of public goods should become the subject of extensive economic analyses which address in particular the agriculture and rural areas. The valuation of environmental resources and external economies generated by the agriculture becomes a major challenge for the economists. The continuously improved scientific methods for the valuation of nonproduction functions (including public functions) of agriculture are not yet fully accepted in economic practice for various reasons (subjective ratings, absence of relevant legal regulations or the inability to use the relevant legal regulations in agricultural accounting). Therefore, it becomes imperative to disseminate the broad range of tools for the analysis of public goods, including valuation methods.

\section{References}

(Adamowicz 2005) Adamowicz, M. 2005. Zrównoważony i wielofunkcyjny rozwój rolnictwa a agronomia. Annales UMCS, Vol. LX, Sec. E, 60,pp. 71-91.

(Baum 2007) Baum, R., Wielicki, W. 2007. Prognoza przeobrażeń w rolnictwie do roku 2030 w kontekście zrównoważonego rozwoju. Wieś i Rolnictwo, 1(134), pp. 19-32.

(Baum 2009) Baum, R.; Śleszyński, J. 2009. Nowe funkcje rolnictwa-dostarczanie dóbr publicznych. Roczniki Naukowe SERiA, T. XI, Z. 2, pp. 19-23.

(Baum 2011) Baum, R. 2011. Ocena zrównoważonego rozwoju w rolnictwie (studium metodyczne). Rozprawy Naukowe 434. Uniwersytet Przyrodniczy w Poznaniu, Poznań. 
(Black 2009) Black, J., Hashimzade, N., Myles, G. 2009. Dictionary of Economics. Oxford University Press, Oxford. pp. 160.

(Coase 1960) Coase, R. 1960. The Problem of Social Cost. Journal of Law and Economics. Vol. 3, pp. 1-44.

(FAPA/SAEPR 2006) FAPA/SAEPR,. 2006. Wstępna analiza instrumentu cross-compliance w kontekście przyszłej implementacji w Polsce. Fundacja Programów Pomocy dla Rolnictwa. Sekcja Analiz Ekonomicznych Polityki Rolnej, Warszawa.

(Fiedor 2002) Fiedor, B. (eds.). 2002. Podstawy ekonomii środowiska i zasobów naturalnych. C.H. Beck Warszawa.

(Grzelak 2010) Grzelak, A. 2010. Rolnictwo wobec wybranych wyzwań ekonomicznych. Zeszyty Naukowe SGGW. Ekon i Org. Gosp. Żywn., 85, pp. 5-18.

(Graczyk 2013) Graczyk, A., Kociszewski, K. 2013. Teoretyczne i aplikacyjne aspekty wyceny środowiskowych efektów zewnętrznych w rolnictwie. In: Zegar, J. St. (eds).: Z badań nad rolnictwem społecznie zrównoważonym (19). Raport nr 68, pp. 43-94, IERiGŻ PIB Warszawa.

(Holcombe 1997) Holcombe, R.G. 1997. A Theory of the Theory of Public Goods. Review of Austrian Economics, 10(1), pp. 1-22.

(Landreth 1998) Landreth, H.; Colander, D. 1998. Historia myśli ekonomicznej. PWN, Warszawa, pp. 87.

(Łuczka-Bakuła 2006) Łuczka-Bakuła, W. 2006. W kierunku rolnictwa zrównoważonego-od programów rolnośrodowiskowych do Cross-Compliance. Zeszyty Naukowe AR Wrocław, Rolnictwo LXXXVII, 540, pp. 291-296.

(Maciejczak 2009) Maciejczak, M. 2009. Rolnictwo i obszary wiejskie źródłem dóbr publicznych-przegląd literatury. Zeszyty Naukowe SGGW, Ekonomika i Organizacja Gospodarki Żywnościowej, 75, pp. 121-134.

(Maciejczak 2010) Maciejczak, M. 2010. Modyfikacje genetyczne w rolnictwie w świetle nowej ekonomii instytucjonalnej. Roczniki Naukowe SERiA, T. XII, Z.1, pp. 110-116.

(Majewski 2008) Majewski, E. 2008. Trwały rozwój i trwałe rolnictwo. Teoria a praktyka gospodarstw rolniczych. SGGW, Warszawa .

(Marshall [1890] 2018) Marshall, A. 1890. Principles of Economics. 8th Edition, Macmillan, London, http://www.econlib.org/library/Marshall/marP.html, last accessed 2018/06/26.

(Panasiuk 2001) Panasiuk, D. 2001. Wycena środowiska metodą kosztów podróży w praktyce. Wartość turystyczna Pienińskiego Parku Narodowego. Ekonomia a rozwój zrównoważony. Tom 2, Ekon. i Środ., Białystok, pp. 264-277.

(Pigou [1932] 2018) Pigou, A. C. 1932. The Economics of Welfare. 4th Edition Macmillan and Co., London, http://www.econlib.org/library/NPDBooks/Pigou/pgEW.html, last accessed 2018/06/27.

(Piontek 2002) Piontek, B. 2002. Koncepcja rozwoju zrównoważonego i trwałego Polski. PWN, Warszawa.

(Rogall 2009) Rogall, H. 2009. Nachhaltige Ökonomie. Ökonomische Theorie und Praxis einer Nachhaltigen Entwicklung. Auflage 2, Metropolis, Marburg.

(Runowski 2005) Runowski, H. 2005. Systemy rolnictwa w scenariuszu przyszłości. Wilkin J. (eds.) Polska wieś 2025. Wizja rozwoju, IRWiR PAN, Warszawa.

(Sadowski 2009) Sadowski, A. 2009. Gospodarstwa rolne w koncepcji polityki zrównoważonego rozwoju obszarów wiejskich. Journal of Agribusiness and Rural Development 2(12), pp. 167-173.

(Samuelson 1954) Samuelson, P.A. 1954. The Pure Theory of Public Expenditure. The Review of Economics and Statistics, Vol. 36, No. 4, pp. 387-389.

(Samuelson 1995) Samuelson, P.A.; Nordhaus, W.D. 1995. Ekonomia 1. PWN, Warszawa, pp. 91.

(Samuelson 1996) Samuelson, P.A.; Nordhaus, W.D. 1996. Ekonomia 2. PWN, Warszawa, pp. 236.

(Shechter 1996) Shechter, M. 1996. Wycena środowiska. Folmer H. et al. (eds.) Ekonomia środowiska i zasobów naturalnych. Krupiński i S-ka, Warszawa.

(Stiglitz 2004) Stiglitz, J.E. 2004. Ekonomia sektora publicznego. PWN, Warszawa, pp. 254.

(Wesołowska [2004] 2018) Wesołowska, A. 2004. Teoria dóbr publicznych Paula Anthony'ego Samuelsona. Dialogi Polityczne, UMK w Toruniu, 2/2004 Liberalizm, http://www.dialogi.umk.pl/teoria-dobrpublicznych-samuelson.html, last accessed 2018/06/29.

(Wilkin 2005) Wilkin, J. 2005. (eds.): Teoria wyboru publicznego. Wstęp do ekonomicznej analizy polityki $i$ funkcjonowania sfery publicznej. Scholar, Warszawa.

(Wilkin 2009) Wilkin, J. 2009. Wielofunkcyjność rolnictwa-konceptualizacja i operacjonalizacja zjawiska. Wieś $i$ Rolnictwo, 4, pp. 9-28.

(Woś 2002) Woś, A.; Zegar, J.S. 2002. Rolnictwo społecznie zrównoważone. IERiGŻ, Warszawa.

(Zegar 2007) Zegar, J.S. 2007. Społeczne aspekty zrównoważonego rozwoju rolnictwa. Fragmenta Agronomia 4 (96), pp. 282-298. 
(Zegar 2012) Zegar, J.S. 2012. Konkurencyjność ekonomiczna versus konkurencyjność społeczna w rolnictwie. Prace Naukowe Uniwersytetu Ekonomicznego we Wrocławiu 246, pp. 563-573.

(Żylicz [2013] 2018) Żylicz, T. 2013 Wycena usług ekosystemów leśnych. A paper presented at the "Value” Expert Panel. $\begin{array}{llllll}\text { Instytut } & \text { Leśnictwa } & \text { Sękocin } & \text { Stary, } & \text { October } & 15,\end{array}$ http://www.npl.ibles.pl/sites/default/files/referat/referat_zylicz_t.pdf, last accessed 2018/06/26. 